\title{
MSA, The French Agricultural Social Protection scheme
}

\author{
Anne Roudot, Ghislaine Rosay
}

\begin{abstract}
As the second largest social protection scheme in France, the Agricultural Social Mutuality (fr. Mutualité sociale agricole, MSA) is responsible for providing all compulsory social security coverage for the entire agricultural population and its beneficiaries, whether it concerns health, family, retirement, work-related accidents or occupational diseases. The MSA is responsible for collecting social security premiums and contributions, but also unemployment insurance and conventional contributions for many organizations ${ }^{1}$.

It differs from other French social security schemes in that it provides a one-stop shop for individuals and companies to deal with a single contact person for all matters relating to their social protection throughout their lives.

In addition to its basic mission, it carries out a policy of health and social action adapted to its population and is also in charge of occupational medicine and the prevention of professional risks in the agricultural sector. It can support all actions aiming to promote the coordination and the offer of care in rural areas ${ }^{2}$.

As a mutualistic organization, the MSA is the expression of a responsible and supportive democracy at the service and in proximity of the rural world. The representativeness of its elected delegates, its knowledge of the territories and their stakeholders, and its role as a professional agricultural organization give it an indispensable expertise that allows it to work for the cohesion of the territories while guaranteeing access to quality public services.

This expertise also enables it to be present abroad as part of formalized exchanges in European networks and international cooperation projects.
\end{abstract}

Keywords: agriculture, agricultural scheme, insurance, MSA, social protection.

1. Mutualité sociale agricole (MSA), Présentation de la MSA, https://www.msa.fr/lfy/identite/nos-valeurs, access 16.06.2020.

2. Article L723-2 of the Rural and Maritime Fishing Code.

Anne Roudot, Cabinet of the Presidency and the Directorate General, Head of Mission within the International Relations and Control Department, Mutualité sociale agricole (MSA); Ghislaine Rosay, Cabinet of the Presidency and the Directorate General, Head of the International Relations and Control Department, Mutualité sociale agricole (MSA). 


\title{
The origins of the $\mathrm{MSA}^{3}$
}

\author{
A mutualism based primarily on economic solidarity
}

In the second half of the 19th century, in order to face the difficulties caused by the loss of livestock or the destruction of crops, farmers created local mutual insurance companies. They had no defined status until the law of 1884 relating to trade unions, which recognized the right of farmers to professional representation, and the law of July 4,1900 , which definitively validated the existence and the free formation of agricultural mutual insurance funds. This was the starting point for the development of agricultural insurance: insurance against accidents, hail, fire, etc.

Between 1900 and 1920, 15,000 agricultural mutual insurance companies were structured at several levels (local, departmental, regional and national).

\section{Transition from mutualism to national solidarity}

From 1930 onwards ${ }^{4}$, Social Insurance (French: ASA) became compulsory, with all employees being subject to it and employers participating in it, and it was paid for by the funds. However, the legislator intervened by channelling the majority of memberships from the agricultural world to the Agricultural Mutual Aid Societies. The year $1935^{5}$ thus saw the development of the social branch of the Agricultural Mutuality.

The right to family allowances (French: PFA) for heads of families and the obligation to contribute for all employers appeared in 1932 in France. They were implemented in $1936^{6}$ for agricultural employees and in $1939^{7}$ for farmers. Management was also taken over by the agricultural mutual aid societies.

After the 1939-45 war, social benefits comparable to those of other socio-professional categories were gradually acquired by agricultural workers; the most notable fact being the compulsory insurance against accidents at work and occupational diseases ${ }^{8}$.

3. Mutualité sociale agricole (MSA), The populations of the agricultural scheme in 2016 - Statistical yearbook, statistiques.msa.fr, access 16.06.2020.

4. Official Journal of the French Republic (JO) no. 0104, 1 May 1930, p. 4819.

5. Decree-Law of 30 October 1935.

6. Official Journal of the French Republic (JO) no. 0184, 7 August 1936, p. 8453.

7. Decree-Law of 29 July 1939.

8. Act no. 72-965 of 25 October 1972, Official Journal of the French Republic (JO) no. 0251, 26 October 1972, p. 11196. 
The unification of all the mutualistic institutions by branch of activity in a defined district began in $1940^{\circ}$ and became more specific the following year: under the supervision of the Ministry of Agriculture, the application of social laws in agriculture was entrusted solely to the professional agricultural mutual funds.

The Agricultural Social Mutuality was officially confirmed as a professional organization whose mission was to manage all social risks for insured farmers. With the law of April 5, 1941, the law institutionalized a de fact o situation: the one-stop shop, characteristic of the organization of the agricultural system adapted to the specificity of the rural world.

With the ordinance of October 4, 1945, which affirmed the principle of the universality of Social Security and provided for the maintenance of the plurality of schemes, the MSA continued its action in the agricultural sector and set up an elective system in 1949. The MSA was thus managed in a democratic and professional manner.

In 1947, a public service mission was entrusted to the MSA for the management of 2 social benefit schemes for the agricultural world.

Since 1949, the social protection system (health, family, retirement, prevention, social action) has developed within the framework of an institution that preserves its mutualist values.

Social security coverage for farmers was not established until later: immediately after the war, they only received family allowances. The Agricultural Old Age Insurance (French: AVA) was created in 1952. But above all, the sickness, maternity and disability insurance (AMEXA), created in $1961^{10}$, was an essential step in the history of social protection. It made farmers the first self-employed people to benefit from health insurance.

In 2002, a new branch of agricultural social protection was created ${ }^{11}$, making it compulsory for non-salaried agricultural workers to be covered against accidents at work and occupational diseases (ATEXA). It could be managed by several operators, including the MSA. As of January 1, 2014, this possibility was abolished by the legislator and all non-salaried agricultural workers were insured by the MSA ${ }^{12}$.

Finally, in 2003, the compulsory supplementary pension (RCO) was created for farm or farming company managers. However, it was not until $2010^{13}$ that it was extended to family assistants and farm or farming company employees.

9. Official Journal of the French Republic (JO) no. 316, 7 December 1940, p. 6005.

10. Act no. 61-89 of 25 January 1961, Official Journal of the French Republic (JO) no. 0023, 27 January 1961, p. 1059.

11. Official Journal of the French Republic (JO) no. 0279, 1 December 2001, p. 19106.

12. Social Security Financing Act for 2014.

13. Act of 9 October 2010 on pension reform. 


\title{
Organization and missions of the MSA
}

\author{
A strong presence in the territories
}

The Agricultural Social Mutuality, a professional organization under private law with a public service mission, is placed under the joint supervision of the Ministry of Agriculture, the Ministry of Action and Public Accounts, and the Ministry of Health.

In order to be as close as possible to its policyholders, the MSA is organized in a network and is based on a decentralized structure. The Central Fund (CCMSA) represents the MSA at the national level. At the territorial level, 35 departmental or multi-departmental funds are the single point of contact for policyholders. The funds cover a maximum of four departments, with the exception of the Ile-de-France regional fund, in order to respect geographical and cultural identities, economic balances and distances between sites. The proximity of the agricultural scheme is also reflected in the more than 1,400 local agencies. A total of 17,000 employees work daily for MSA members, including 1,500 social workers, 350 doctors and 280 prevention advisors ${ }^{14}$, as well as 9,000 employees deploying its health and social services.

\section{A democratic and mutualistic institution}

The MSA is an institution with an elective structure representing the entire agricultural population. Elections are held every 5 years to elect the cantonal delegates and the administrators of the MSA funds, thus making the MSA a democratic and mutualistic institution.

In 2020, 13,760 cantonal delegates ${ }^{15}$, divided into 3 colleges: farmers, employees and employers of labour, were elected to represent 3 million voting members. In turn, these delegates elected the 1,071 directors at the departmental, multi-departmental and national levels ${ }^{16}$. At the end of the electoral process, the directors of the 35 funds, as well as those of the central fund, are elected. They participate, within the boards of directors, in defining institutional policies, ensuring their application and setting management

14. Mutualité sociale agricole (MSA), Mutualism in MSA, https://www.msa.fr/lfy/identite/le-mutualisme, access 16.06.2020.

15. Mutualité sociale agricole (MSA), Qu'est-ce qu’un élu MSA?, https://www.msa.fr/lfy/elections-msa/ delegue-cantonal, access 16.06.2020.

16. Mutualité sociale agricole (MSA), Le mutualisme, une force, https://www.msa.fr/lfy/identite/le-mutualisme, access 16.06.2020. 
guidelines. The political governance of the network is the responsibility of the central general assembly and the central council, which elects the president of CCMSA.

With this system, a true democracy is at work because the elective structure is based on the principle of "one person, one vote" and represents all categories of insured. This is how the social link is maintained around issues of concern to the rural world, whether they be sectorial crises or health and social issues.

The mutualistic action of the MSA differs from that of the other agents in the world of social protection. It takes the form of proximity, dialogue and a global vision of agricultural and rural issues for the entire agricultural and rural population and for elected officials. It also enables it to launch health and social experiments with its partners and the public authorities, and to carry out concerted, innovative and tailor-made actions that produce tangible results. Mutualism is both a collective decision and an individual initiative. It is the pooling of resources as well as knowhow. This is reflected in the daily commitment of thousands of elected officials, men and women actively working, who act on a voluntary basis ${ }^{17}$.

\section{The MSA, the social operator of the agricultural world}

The MSA provides social security coverage for the entire agricultural population: farmers; employees of farms, businesses, cooperatives and professional agricultural organizations; employers of labour; agricultural retirees; dependents of the above-mentioned people (spouse or partner if not working, children, etc.).

Affiliation to the MSA is compulsory and depends on the type of professional activities carried out as defined by the Rural and Maritime Fishing Code ${ }^{18}$.

In 2018, 1,100,000 working people were affiliated with the agricultural social security system: 477,603 non-salaried agricultural workers: farm managers, farm employees, family helpers (42\%) and 658,441 salaried workers $(58 \%)^{19}$.

The MSA's one-stop shop allows members of the agricultural social security system, whether salaried or non-salaried, active or retired, to be accompanied throughout their lives by the fund to which they are affiliated for all matters relating to their social protection. The funds can thus offer appropriate support to insured persons and their families, which is particularly important in the event of difficulties.

17. Mutualité sociale agricole (MSA), Lesélus porteurs de l'innovation sociale. Rapport mutualiste 2018, https:// www.msa.fr/lfy/documents/11566/82466756/Rapport+mutualiste+MSA+2018.pdf, access 16.06.2020. 18. For employees Article L. 722-20 and following of the Rural and Maritime Fishing Code/For non-salaried employees Article L. 722-1 and following of the Rural and Maritime Fishing Code.

19. Mutualité sociale agricole (MSA), Les chiffres utiles de la MSA - Edition nationale 2019, statistiques. msa.fr, access 16.06.2020. 
With this one-stop shop, the MSA differs from the general social security scheme, where members are managed by four independent funds: the CNAV for retirement, the CNAF for the family, the CNAM for sickness, work accidents and occupational diseases, and the ACOSS and URSSAF for contributions.

Thus, in the areas of health, family, retirement, work-related accidents and occupational diseases, the MSA pays all the legal benefits of these branches, and collects premiums and social contributions, as well as unemployment insurance and conventional contributions for many organizations.

In 2018, nearly one person in ten in France received one or more benefits provided by the MSA, i.e. 5.6 million people ${ }^{20}$ :

- 3.8 million retirement benefits are paid to 3.3 million beneficiaries, knowing that nearly 500,000 retirees simultaneously receive a pension for salaried employees and non-salaried agricultural workers.

- 3.2 million people are eligible for reimbursement under a health benefit.

- More than 400,000 families receive one or more family, housing, solidarity and/or disability-related benefits and the number of children dependent on these families is nearly 450,000 .

- 2.2 million people are covered against accidents at work and occupational diseases (1.6 million agricultural employees and nearly 550,000 non-salaried agricultural employees).

In addition, the MSA also provides complementary health insurance for salaried and non-salaried agricultural workers who meet certain requirements ${ }^{21}$. It manages the compulsory supplementary pension scheme for non-salaried agricultural workers.

It also manages, on behalf of partner organizations, supplementary social protection in terms of retirement, health and provident funds.

Finally, in addition to legal social protection, the MSA carries out a policy of health and social action in the field of solidarity, disability and dependency, which benefits 3.3 million people ${ }^{22}$.

The MSA is also in charge of occupational risk prevention/health and safety in agriculture and occupational medicine.

20. Mutualité sociale agricole (MSA), Les chiffres utiles de la MSA - Edition nationale 2019, statistiques. msa.fr, access 16.06 .2020

21. Article L. $861-1$ of the Social Security Code.

22. Mutualité sociale agricole (MSA), Les chiffres utiles de la MSA - Edition nationale 2019, statistiques. msa.fr, access 16.06 .2020 


\section{MSA funding}

\section{The budgetary framework ${ }^{23}$}

A five-year Agreement of Objectives and Management (French: COG), signed between the MSA and the State, formalizes the delegation of management of the public social security service. This agreement, established by the 1996 social security reform plan ${ }^{24}$, sets out the objectives to be achieved and the means to be implemented to modernize and improve the performance of the social protection system, both in terms of controlling expenditure and providing better service to users.

The COG and its objectives are national in scope and are then translated into operational guidelines in the form of multi-year management contracts (French: CPG) between the central fund and the local MSA funds. The CPG specifies for each area and for each organization, in the form of indicators, the concrete actions to be implemented and the results to be obtained, taking into account the conditions of implementation at the local level.

\section{Expenditures of the agricultural scheme $e^{25}$}

The expenses of the agricultural scheme (salaried and non-salaried employees), amounted to nearly 32.5 billion euros in 2018 . This amount covered the legal expenses related to the four branches - illness, work-related accidents and occupational diseases, family ${ }^{26}$, retirement including the mandatory supplementary pension (French: RCO) for non-salaried agricultural workers. It also includes non-statutory expenses to finance health and social actions.

Statutory and non-statutory social benefits account for $82.5 \%$ of the scheme's expenditure, or 26.8 billion euros.

The pension branch represents almost half of the social benefits paid by the agricultural scheme (13.1 billion euros).

The total amount of sickness, maternity, disability, death, daily sickness benefits and paternity leave benefits amounts to more than 11.2 billion euros.

23. La Sécurité sociale, www.securite-sociale.fr, access 16.06.2020.

24. Order no. 96-344 of 24 April 1996, Official Journal of the French Republic (JO) no. 0098, 25 April 1996, p. 6301.

25. Mutualité sociale agricole (MSA), Les chiffres utiles de la MSA - Edition nationale 2019, statistiques. msa.fr, access 16.06.2020.

26. These amounts do not include all of the benefits paid by the agricultural scheme for the family branch; only family benefits are recorded in the agricultural scheme's accounts. 


\section{The revenues of the agricultural scheme}

The agricultural scheme's revenues are made up of: one-third from financing by workers; more than $27 \%$ from transfers between social security organizations, notably for demographic compensation for old age; the remaining third from transfers from the General Scheme, which balance the balances of the agricultural scheme's health and family branches (18.0\% of revenues), taxes and duties allocated (nearly $15 \%)$ and other financial income (5\%).

Financing by workers. Financing by workers is composed of social contributions paid by members of the agricultural scheme, i.e. farm managers, their spouses and family assistants, farm managers and their employees, and of the Generalized Social Contribution (French: CSG) paid by members of the agricultural scheme on their working or replacement income. These contributions are collected by the MSA.

Social security contributions based on all or part of remuneration exist for all branches $^{27}$ (sickness-maternity-disability, old age, work accidents, family). In addition to these contributions, there are exempt contributions paid by the State or those compensated by tax revenues.

The CSG is a tax created in 1991 to make the financing of social protection more equitable by transferring part of the contributions levied only on salaries to a levy on all income, salaried or non-salaried ${ }^{28}$.

Transfers between social security bodies as compensation. Compensation mechanisms between social security organizations have been set up for the pension branch for non-salaried agricultural workers and for the occupational injury branch for agricultural workers. These social security schemes are the General Scheme, the CCMSA, the schemes for civil servants and military personnel, the National Retirement Fund for Local Authority Employees (CNRACL), which manages the scheme for local and hospital civil servants, and the National Old Age Insurance Fund for the liberal professions.

In order to correct demographic imbalances and contribution disparities between basic pension schemes, a financial solidarity mechanism was introduced in $1974^{29}$. This is the demographic compensation for old age, which aims to distribute the costs of each scheme more fairly. These financial transfers, which go from the

27. Rural and Maritime Fishing Code.

28. Act no. 90-1168 of 29 December 1990, Official Journal of the French Republic (JO) no. 0303, 30 December 1990, p. 16367.

29. Act no. 74-1094 of 24 December 1974, Official Journal of the French Republic (JO) no. 0301, 26 December 1974, p. 13020. 
schemes with the best demographic ratio to those with the greatest deficits, can represent a significant part of the revenues of the beneficiary schemes.

A specific compensation between the occupational injury and disease (French: ATMP) branch of the general scheme and the occupational injury and disease branch of the agricultural workers' scheme ${ }^{30}$ allows balancing the cost of pensions according to the payroll of each scheme. However, the occupational injury and disease branch of the agricultural employees' scheme remains autonomous insofar as it does not benefit from transfers from the general scheme to balance its overall balance. Any deficit is therefore borne by the agricultural scheme.

Balancing transfers from the general scheme. The balancing transfers from the general scheme concern the health and family branches of the agricultural scheme (employees and non-salaried workers), and the pension branch of the agricultural employees' scheme.

The health insurance branch has been financially integrated with the National Health Insurance Fund (fr. Caisse Nationale d'Assurance Maladie - CNAM) since $1963^{31}$ for the agricultural employees' scheme and since $2009^{32}$ for the non-salaried agricultural employees' scheme (excluding AMEXA daily benefits). As such, the CNAM balances the overall balance of the health insurance branch through a "balancing transfer", the amount of which may be positive or negative depending on whether it is a revenue or an expense for the agricultural scheme.

Since $2014^{33}$, the expenditures and revenues of the family branch of the agricultural scheme (salaried and non-salaried employees) have been fully integrated into the accounts of the National Family Allowance Fund (fr. Caisse nationale des allocations familiales - CNAF).

Since $1963^{34}$, the pension branch of the agricultural employees' scheme has been financially integrated into that of the National Old Age Insurance Fund (fr. Caisse Nationale d'Assurance Vieillesse - CNAV), which thus ensures its balance. On the other hand, the pension branch (basic and supplementary) and the occupational injury and disease branch (ATEXA) for non-salaried agricultural workers do not have a balancing mechanism and any deficits are therefore borne by the non-salaried agricultural workers' scheme.

30. Articles L.134-7 to L.134-11 of the Social Security Code.

31. The 1963 Finance Act.

32. Social Security Financing Act for 2019.

33. Social Security Financing Act for 2014.

34. The 1963 Finance Act no. 63-156 of 23 February 1963, Official Journal of the French Republic (JO) no. 0047, 24 February 1963, p. 1818. 
Allocated taxes and duties. The allocated taxes and duties are fiscal resources assigned by the State to finance social benefits or specific expenses. For example, a tax on alcoholic beverages and on sweetened beverages, a tax on tobacco consumption, a tax on food products, a share of the proceeds of the social contribution for corporate solidarity (C3S), etc., are allocated to the agricultural scheme.

\section{Statutory benefits}

As part of its mission of compulsory social protection, the MSA covers salaried and non-salaried agricultural workers in four branches (health, retirement, family, work-related accidents and occupational diseases). In order to ensure that insured individuals receive all the benefits to which they are entitled, the MSA offers an individual support system called "Rendez-Vous Prestations". In this way, the MSA can identify people in difficulties and facilitate the procedures for the allocation of the social benefits it manages.

\section{Sickness, maternity, paternity, disability and death insurance}

As soon as the non-salaried person meets the establishment conditions, the signature of his or her affiliation file marks his or her entry into the health insurance scheme for farmers (AMEXA). Similarly, for employees, the beginning of their agricultural activity marks their entry into the health insurance scheme for agricultural employees. They thus have access to health benefits for themselves and their family members.

Health care ${ }^{35}$. The MSA reimburses part or all of the health care costs incurred (medical, pharmaceutical and dental care) by the insured (salaried, non-salaried or retired) or by certain members of his or her family on the basis of the rates in force. The portion that remains at the insured's expense can be compensated by a complementary health insurance plan. The MSA may have negotiated partnerships with complementary health insurance companies and, in this case, it directly covers the insured's health reimbursements for both the compulsory and complementary portions.

35. Mutualité sociale agricole (MSA), Votre couverture santé MSA, https://www.msa.fr/lfy/sante/couverture-msa, access 16.06.2020. 
Since January 1, 2016 $6^{36}$, the Universal Health Protection has guaranteed coverage of health care costs on the condition that you reside in France for at least six months a year on a stable and regular basis.

Daily sickness benefits ${ }^{37}$. Daily sickness benefits are paid by the MSA to compensate for the loss of income from activities (salaries or non-salaried income) due to a work stoppage following an illness. These allowances are subject to conditions and vary according to the length of the sick leave.

Maternity leave $\mathrm{e}^{38}$. It lasts 16 weeks and concerns both salaried and non-salaried workers. It starts 6 weeks before the presumed date of delivery and continues 10 weeks after the birth.

The young mother who is employed can maintain her level of income during this period of leave thanks to daily maternity allowances and the young mother who is not employed can be replaced on the farm or her agricultural business and benefit from a replacement allowance.

Paternity leave ${ }^{39}$. The legal leave period is 11 consecutive days or 18 consecutive days in the case of multiple births. The conditions for receiving daily paternity benefits are the same as those for maternity benefits for employees, and the amounts are also equivalent. Insured persons who are not employees are entitled to a paternity replacement allowance.

Disability Insurance ${ }^{40}$. In the event of total or partial incapacity to exercise the agricultural profession, the disability insurance allows for the granting of a disability pension, provided certain requirements are met.

Death benefit ${ }^{41}$. The beneficiary of the deceased's right to health insurance benefits is entitled to continue to receive them as of the death of the spouse. Subject to certain conditions, and if the spouse was an agricultural employee, he or she may be entitled to a lump-sum death benefit.

There is no death benefit for non-salaried agricultural workers

36. Social Security Financing Act for 2016.

37. Mutualité sociale agricole (MSA), L'indemnité journalière Amexa pour les exploitants et leur famille, https://www.msa.fr/lfy/web/msa/sante/ij-amexa, access 16.06.2020; Mutualité sociale agricole (MSA), Larrêt de travail pour maladie des salaries, https://www.msa.fr/lfy/web/msa/sante/arret-travail-maladie, access 16.06.2020.

38. Mutualité sociale agricole (MSA), Le congé maternité, https://www.msa.fr/lfy/web/msa/sante/ conge-maternite, access 16.06.2020.

39. Mutualité sociale agricole (MSA), Le congé de paternité et d'accueil de l'enfant, https://www.msa.fr/lfy/ $\mathrm{web} / \mathrm{msa} /$ sante/conge-paternite, access 16.06.2020.

40. Mutualité sociale agricole (MSA), L'invalidité et l'inaptitude médicale au travail, https://www.msa.fr/ lfy/web/msa/sante/invalidite-inaptitude, access 16.06.2020.

41. Mutualité sociale agricole (MSA), Vous avez perdu un proche, https://www.msa.fr/lfy/pratique/vousavez-perdu-un-proche, access 16.06.2020. 


\section{Old age and widowhood insurance}

Retirement for agricultural workers ${ }^{42}$. As soon as an active person has contributed at least 1 quarter to the agricultural scheme for salaried workers, he/she can obtain a pension composed of a basic pension from the MSA and a supplementary pension from the Agirc-Arrco.

The basic pension is calculated on the basis of the average annual salary of the 25 best years of career, the length of insurance and the rate of liquidation.

The supplementary pension (compulsory pay-as-you-go pension scheme for all private sector employees) is based on points. The sum of the points attributed to the employee during his or her professional career is multiplied by the value of the point at the time of his or her retirement.

Retirement of non-salaried agricultural workers ${ }^{43}$. The pension of a farmer, farming company manager, a collaborator or a family helper is composed of a basic pension and a compulsory complementary pension (French: RCO) managed by the MSA.

The basic pension includes a flat-rate pension (when the non-salaried agricultural activity is carried out as the exclusive or main occupation) and a proportional pension based on points.

The RCO is also point-based and was implemented in $2003^{44}$.

The reversionary pension ${ }^{45}$. Upon the loss of a spouse, the survivor may obtain, under certain conditions, a reversionary pension. It represents a portion of the pension that the deceased spouse received or could have received. The reversionary pension is means-tested and is awarded to spouses and/or ex-spouses from the age of 55.

Widowhood allowance ${ }^{46}$. It can be granted to the surviving spouse, if he/she is not yet old enough to apply for a reversionary pension, for a period of 2 years. The amount is unique and means-tested.

42. Mutualité sociale agricole (MSA), La retraite des salariés agricoles, https://www.msa.fr/lfy/web/msa/ retraite/salaries-agricoles, access 16.06.2020.

43. Mutualité sociale agricole (MSA), La retraite des non-salariés agricoles, https://www.msa.fr/lfy/web/ $\mathrm{msa} /$ retraite/non-salaries-agricoles, access 16.06.2020.

44. Act no. 2002-308 of 4 March 2002, Official Journal of the French Republic (JO) no. 0054, 5 March 2002, p. 4171.

45. Mutualité sociale agricole (MSA), Pension de reversion, https://www.msa.fr/lfy/web/msa/retraite/reversion), access 16.06.2020.

46. Mutualité sociale agricole (MSA), L’allocation veuvage, https://www.msa.fr/lfy/web/msa/retraite/allocation-veuvage, access 16.06.2020. 


\section{Family, housing and solidarity benefits ${ }^{47}$}

To help reconcile family and professional life, the MSA manages all legal benefits concerning children and families of employees and farmers. The payment of most of these benefits is means-tested and the amount may vary.

Family benefits. These benefits are intended to provide families with assistance to partially compensate for the expenses incurred for the subsistence and education of children (family allowances starting with the 2 nd child, family allowance starting with the 3rd child, family support allowance...).

Benefits are more specifically dedicated to childbirth and early childhood care: childcare benefit for young children (French: PAJE); shared child-rearing benefit (French: Prepare) paid to parents who reduce work or stop working to devote themselves to the education of their children.

Other benefits are earmarked for special purposes: the daily parental presence allowance (French: AJPP), which provides financial assistance to stay with a seriously ill, injured or disabled child and compensate for the financial loss related to the temporary cessation of professional activity; the back-to-school allowance to compensate for the expenses incurred by the start of the new school year for children aged 6 to 18 ; and the education allowance for disabled children under 20 years of age (French: AEEH), which provides financial assistance to contribute to their education and care.

Housing allowances. Depending on the situation, three different types of housing assistance may be paid by the MSA: the Personalized Housing Assistance (French: APL) to reduce the amount of rent or monthly loan payments in the case of home ownership; the Family housing allowance (French: ALF) for people who are not eligible for the APL and who meet certain conditions; and the Social housing allowance (French: ALS) for people who are not eligible for the APL and ALF.

Benefits related to disability or solidarity. An allowance is paid to disabled adults (French: AAH) to guarantee them a minimum income, in the absence of resources or in case of modest income ${ }^{48}$.

An Active Solidarity Income (French: RSA) allows job seekers and agricultural workers with low incomes to benefit from an income guarantee $e^{49}$.

An Activity Allowance is a supplement to income not exceeding a certain amount.

47. Mutualité sociale agricole (MSA), Famille, lodgement, https://www.msa.fr/lfy/famille-logement, access 16.06 .2020 .

48. Mutualité sociale agricole (MSA), Lallocation aux adultes handicapés (AAH), https://www.msa.fr/lfy/ handicap/allocation-adultes-handicapes, access 16.06.2020.

49. Mutualité sociale agricole (MSA), Le RSA, mode demploi, https://www.msa.fr/lfy/rsa/mode/emploi, access 16.06.2020. 


\section{Insurance against industrial accidents and occupational diseases ${ }^{50}$}

An accident at work or an occupational disease can lead employees and non-employees to temporarily or permanently stop their activity. Agricultural workers are protected by the MSA in the event of a work-related accident or illness.

An occupational disease is the direct consequence of a more or less prolonged exposure to a physical, chemical or biological risk during a professional activity. It can also be the result of the conditions in which this activity is carried out. The recognition of the professional nature of the disease entitles to various benefits (compensation for temporary disability, compensation for permanent disability...).

The occupational diseases recognized and covered by the MSA are listed in tables of occupational diseases specific to agricultural professions. Each of them, published by decree, specifies the medical, technical and administrative conditions to be met (designation of the disease, time limit for coverage, duration of exposure to the risk, if applicable, and list of work performed). A regional committee for the recognition of occupational diseases (French: CRRMP) may, however, carry out an individual assessment and rule on the occupational nature of the disease.

Health care. The MSA reimburses health care (city care, hospitalization, medical transport), and equipment or prostheses related to work accidents/occupational diseases within the limits of the applicable scales.

Daily allowances for non-salaried workers (ATEXA). Lump-sum daily allowances are paid to the head of a farm or agricultural enterprise who is medically unable to work. It is paid from the 8th day following the work stoppage until the date of consolidation or recovery. The daily allowances paid under the ATEXA are lump-sum payments and change over time.

Daily benefits for employees. Daily allowances are paid every 14 days, without a waiting period, until the date of consolidation or recovery. These benefits correspond to a percentage of the basic daily wage with a maximum amount capped and evolve over time.

Compensation for permanent disability. The MSA provides compensation in case of permanent disability of the victim of an accident at work or an occupational disease. It can be paid as a capital sum or as an annuity depending on the permanent disability rate.

50. Mutualité sociale agricole (MSA), Accident, maladie, invalidité, https://www.msa.fr/lfy/sante/accident-maladie-invalidite, access 16.06.2020. 


\section{A preventive health program adapted to the needs of the agricultural and rural population ${ }^{51}$}

Within the framework of its national prevention program, the MSA implements actions that reflect the priorities defined by the public authorities for agricultural and rural populations. It develops targeted actions adapted to the needs of the insured, particularly towards young people, those who under-consume care and prevention, and the most precarious populations. It incorporates innovative, multi-channel prevention strategies into its offer and takes into account the territorial health contracts piloted by the regional health agencies (French: ARS) in its local initiative projects.

\section{The healthy moments}

Personalized and free of charge, they reintegrate people who are far away from city care into the health care system. The insured person is offered an appointment with a nurse to identify his or her health needs and to refer him or her to a general practitioner; a dietician is then present to provide nutritional advice. The insured person then receives a preventive consultation - with the doctor of his or her choice - to enable him or her to take stock of the health issues that are of concern to him or her. Appropriate preventive actions are offered: help to stop smoking, oral health check-up, health nutrition course, collective actions for senior citizens, etc.

\section{National vaccination campaigns}

They are carried out each year by the MSA. The national influenza vaccination campaign raises awareness among vulnerable people (people over 65 years of age and/or those with long-term illnesses) of the importance of getting vaccinated, by offering them vaccines free of charge.

The national measles, mumps and rubella vaccination campaign reminds families of the importance of protecting their children from these diseases.

51. Mutualité sociale agricole (MSA), Prévention santé MSA nos actions sur les territoires en 2018, https://www.msa.fr/lfy/actions-partenaires/prevention-sante-atout-majeur-msa, access 16.06.2020. 


\section{Screening campaigns}

Each year, the MSA launches screening campaigns for certain diseases (breast, uterine, colorectal cancers, etc.). It invites the most concerned populations, according to their sex and age, to undergo free examinations.

Preventive actions target the youngest, such as the M'T dents program. This consists of full coverage of a preventive oral examination and any subsequent treatment for young people aged 6, 9, 12, 15 and 18 .

\section{Comprehensive care concerning the aging process}

The MSA has a policy of comprehensive care for aging people, which takes the form of collective prevention actions. Workshops on cognitive stimulation and falls prevention are the two most frequent themes. The MSA strongly encourages the national and local dynamics of the inter-scheme of pension funds, in particular by providing turnkey collective action engineering and training of facilitators. The intervention methods are based on more interactivity (to make the participant an actor in his or her own health) and thus guarantee the maximum expected effects. A six-month evaluation system makes it possible to adapt the offer to the need and to have data on behavioural changes.

\section{The therapeutic education program}

The MSA implements this program for patients with heart failure, high blood pressure or coronary artery disease. The sessions are led by health professionals specifically trained in the principles of therapeutic patient education and the program's animation tools.

\section{Local initiatives}

They respond to needs identified by the MSA funds in their territories as well as to public health policy objectives. In 2018, the 36 projects funded focused mainly on promoting well-being among young people as well as on the prevention of risky behaviours and were conducted with students in family and rural homes (MFR) or agricultural high schools. They are followed by actions designed for people in precarious situations as well as actions to prevent seniors from becoming dependent.

Finally, health, education and prevention associations in the territories (French: ASEPT) offer services for the elderly (conferences and debates, Ateliers du Bien 
Vieillir, Ateliers Vitalité, Peps Eurêka, falls prevention workshops, nutrition workshops etc.), but also other groups such as young children, young people, the working population and people in precarious situations.

\section{Targeted prevention actions for occupational risks ${ }^{52}$}

Occupational health and safety in agriculture (OHS) is a specificity of the MSA, which is the only French social security scheme in charge of this mission, combining the competences of occupational risk prevention and occupational health for the companies affiliated to the MSA.

\section{OHS issues in the agricultural sector}

They are specific to the agricultural sectors: high number of very small enterprises; presence of salaried and non-salaried workers; interaction with animals; overexposure to machine risks, chemical products, musculoskeletal disorders, and stress linked in particular to "media hype" (pesticides, animal abuse).

Despite OHS actions, “work can still be harmful to health". Thus, occupational diseases are on the rise, work-related accidents, although decreasing, are more costly, and fatal accidents are still too numerous.

MSA's OHS mission is to preserve the health of agricultural professionals in all its components (physical, mental, social) based on three strong values:

- the involvement of farm workers,

- proximity, listening and presence on the ground,

- support for employees, operators and company managers to integrate the principles of occupational risk prevention.

Occupational illnesses, quality of life at work - an essential condition for the health of individuals and the performance of the company - and the employability of aging workers or those with disabilities are concerns in their own right in the prevention approach. 


\section{Health and safety jobs in agriculture}

In each MSA, occupational physicians, occupational health nurses and prevention advisors, with the support of administrative staff, combine their skills within an occupational health and safety team. They share their expertise to promote prevention in agricultural enterprises and farms. They are more than 950 employees in the 35 MSAs and 33 employees at the central fund.

The prevention advisors implement individual and collective actions for the prevention of professional risks. Occupational physicians provide medical examinations of employees, advise employers on working conditions, adaptation of workstations or risk assessment. Occupational health nurses have a preventive role in monitoring occupational health (information and prevention visits, intermediate visits).

The effectiveness of prevention comes from this synergy which takes place, on the one hand, upstream: diagnosis of risks and improvement of knowledge, in order to support companies that carry out prevention actions in the field. And on the other hand, downstream: evaluation of actions, adaptation of working conditions following an occupational accident or disease.

\section{The 2016-2020 health and safety plan for the agricultural community}

The social responsibility of the MSA, which is committed to preventing wear and tear on the job and professional exclusion, is at the heart of the plan, which concerns the whole of agriculture.

Based on a local diagnosis of risks in agricultural enterprises and an analysis of the national accident rate, the plan focuses on primary prevention, quality of life at work and the fight against professional exclusion.

This plan includes 7 orientations and 6 priorities.

The 7 orientations are as follows:

- evaluate risks, develop a culture of prevention,

- move towards primary prevention by improving knowledge of risk factors, by integrating prevention into initial and continuing education,

- define priorities and targets, demonstrating the nature and impact of the risk, and the number of people affected,

- take into account the specificities of agriculture, in particular animal and chemical risks,

- prevent professional exclusion, 
- develop the quality of life at work, by demonstrating that investing in OHS makes it possible to balance working conditions and company performance,

- develop joint employee-operator actions, integrating the risks for temporary workers, trainees, apprentices and third-party workers.

The plan's six priorities for action:

- animal risk ${ }^{53}$,

- chemical risk ${ }^{54}$,

- falls from height ${ }^{55}$,

- psychosocial risks ${ }^{56}$,

- musculoskeletal disorders ${ }^{57}$,

- employability of agricultural workers ${ }^{58}$.

\section{Health and social support from the MSA ${ }^{59}$}

Beyond its mission of compulsory social protection, the MSA is developing a policy of health and social action through a wide range of services organized to benefit all its members and the entire rural world.

This development strategy is based on MSA's ability to identify the needs of the local population in order to provide appropriate responses through its network of elected officials and technicians.

Thus, its services are aimed at a wide range of people and its initiatives are designed to meet the needs of families, to promote the autonomy of young people, to support working farmers when they are faced with difficulties, to work with the elderly and to support the frail and disabled. On this last point, MSA's action is highly

53. Mutualité sociale agricole (MSA), Risques biologiques et zoonoses, https://ssa.msa.fr/risque/risques-biologiques-et-zoonoses/, access 16.06.2020.

54. Mutualité sociale agricole (MSA), Risques chimiques, https://ssa.msa.fr/risque/risques-chimiques/, access 16.06.2020.

55. Mutualité sociale agricole (MSA), Risques de chutes, https://ssa.msa.fr/risque/risques-de-chutes/, access 16.06.2020.

56. Mutualité sociale agricole (MSA), Risques psychosociaux, https://ssa.msa.fr/risque/risques-psychosociaux/, access 16.06.2020.

57. Mutualité sociale agricole (MSA), Troubles musculosquelettiques, https://ssa.msa.fr/risque/troubles-musculosquelettiques/, access 16.06.2020.

58. Mutualité sociale agricole (MSA), Maintien emploi travailleurs agricoles, https://www.msa.fr/lfy/solidarite/maintien-emploi-travailleurs-agricoles, access 16.06.2020.

59. Mutualité sociale agricole (MSA), La politique daction sanitaire et sociale, https//www.msa.fr/lsy/ politique-action-sanitaire-et-sociale, access 16.06.2020. 
developed and its expertise recognized in its capacity as an expert member of the National Consultative Council of Disabled Persons (French: CNCPH) ${ }^{60}$.

\section{For families}

The MSA has initiated territorial charters to contribute to the improvement of their living environment. These charters aim to strengthen the network of services offered and to promote their social inclusion, in the areas of early childhood, parent-child relations, childhood and youth, social activities and socio-professional support.

The fostering of the young child. To enable families under the agricultural scheme to reconcile work and family life, the MSA co-finances the creation of micro-nurseries, child-minders' homes (French: MAM), child-minders' relays (French: RAM), child and parent reception areas (French: LAEP) and innovative services that provide an appropriate response to the specific needs of families in rural areas.

The MSA provides a benefit for children under six years of age attending nurseries, multi-care centres, drop-in centres, etc. It also provides peri- and extra-curricular care for children under 4 years of age, and supports the provision of leisure activities without accommodation for children and adolescents by paying services directly to the structures and/or by providing aid to families.

Parenting Support. The MSA co-finances family mediation structures and meeting places.

Assistance to go on vacation. It is co-financed by the MSA for families and single people with low incomes who are excluded from going on vacation for financial, organizational and psychological reasons.

The vacation villages of the Agricultural Mutuality (AVMA) ${ }^{61}$. The AVMA, an association of $10 \mathrm{MSA}$ vacation villages and a player in social and solidarity tourism, is a partner in the MSA's health and social action to promote the right to vacations and aims to facilitate access to vacations for all.

\section{For youth in rural areas}

Many young people are attached to their territory and are invested in it. The MSA supports them in their empowerment. As an example, two initiatives have been launched by the younger generation.

60. Gouvernement, Conseil National Consultatif des Personnes Handicapées (CNCPH), https//www.gouvernement.fr/conseil-national-consultatif-des-personnes-handicapees-cncph, access 16.06.2020.

61. AVMA (Association de Vacances de la Mutualité Agricole), https://www.avma-vacances.fr, access 16.06.2020. 
"Better living in rural areas"62. This is a call for youth projects to help them achieve autonomy. It is organized every year by the MSA with a prize-giving ceremony for the 15 winning teams during the International Agricultural Show.

"Youth are committed". This initiative values the creativity and commitment of young people. It is the result of a partnership between the MSAs and the Rural Family Centres (French: MFRs) and aims to support the autonomy and responsibility of candidates.

\section{For agricultural workers ${ }^{63}$}

Farmers, employers or employees may face difficulties in their professional activity. To support them, the MSA offers various support measures: financial aid, support in developing a new professional project, psychological support, etc.

Inclusion workshops. The MSA offers 6 collective actions to support workers in fragile situations, at risk of losing their jobs ("The future in yourself"; "The confidence path"; "Helping hand for connection"; "Taking care of your health"; "Staying together to get going again"; "Continuing differently").

The respite care system. This system is intended for all farmers and employees working in sectors exposed to agricultural crises when they are in a situation of professional exhaustion and in order to allow them a break from their activity.

Prevention and support actions. These actions include leisure activities, vacation stays, discussion groups, psychological consultations, etc.

The prevention of malaise in agriculture. To detect and guide people in psychological distress, the MSA has been carrying out actions since 2011 and has established a national MSA suicide prevention plan in order to better understand the reality of suicide in the agricultural world. It has set up the Agriécoute system (a single telephone number available to MSA insured individuals in great distress), and multidisciplinary suicide prevention cells (French: CPP) bringing together several professions including health and social action, medical control and occupational health and safety. This makes it possible to support insured individuals and their families in the event of suffering or distress.

62. Mutualité sociale agricole (MSA), Le concours "Appel à projets jeunes", https://www.msa.fr/lfy/evenements/apj, access 16.06.2020.

63. Mutualité sociale agricole (MSA), Accompagner les personnes en difficulté, https//www.msa.fr/lsy/ solidarite/accompagner-personnes-difficulte, access 16.06.2020. 


\section{For the elderly ${ }^{64}$}

For nearly 20 years, the MSA has been deploying actions to support ageing people, to prevent loss of autonomy and to maintain the elderly in their living environment. It enables the elderly to remain in their own territory and supports social ties and local solidarity.

Helping people stay in their homes. The MSA's gerontological policy is resolutely focused on home care, with actions that provide a comprehensive understanding of the difficulties that the elderly and their families may encounter:

- promotion of ageing well (health education program for seniors, nutrition, balance),

- support at home (home help, meal delivery, home adaptation),

- support for caregivers (health pathway, "Bulle d'air” (air bubble) respite assistance to relieve caregivers),

- the fight against isolation by maintaining social ties (intergenerational meetings and sharing actions, courtesy visits, organization of transportation on demand).

The MSA is at the origin of the first French teleassistance service with the Présence Verte network, created in $1987^{65}$.

Homes for the Reception and Autonomous Living (French: MARPA) ${ }^{66}$. For elderly people who can no longer stay at home, the MSA offers friendly and secure housing solutions in rural areas. The Homes for the Reception and Autonomous Living (fr. Maisons d'accueil et de résidence pour l'autonomie, MARPA), small living units in rural areas, are alternatives to traditional accommodation for retired people who are still independent in their daily lives but who may be physically and/or morally fragile. The MARPA brand and label are the property of the MSA, which created the social and architectural concept. This "concept" is based on everyone, whether from the area of agriculture or not.

64. Mutualité sociale agricole (MSA), La politique d'action sanitaire et sociale, https//www.msa.fr/lsy/ politique-action-sanitaire-et-sociale, access 16.06.2020.

65. Présence Verte, https://www.presenceverte.fr, access 16.06.2020.

66. Fédération Nationale des Marpa, https://www.marpa.fr, access 16.06.2020. 


\section{For people in fragile situations and people with disabilities ${ }^{67}$}

The MSA supports them throughout their lives, in particular by encouraging the inclusion of disabled children in ordinary schools and by supporting projects to create small living units for aging disabled people. In this way, it helps to improve their living conditions.

Medical and social institutions. In the 1960s, the Central Fund of the MSA initiated the creation of "national establishments" in areas where services were becoming scarce. Their objective is to respond to the needs of people in fragile situations and intervene for care, support, rehabilitation and reintegration in the fields of mental health, physical medicine and rehabilitation, geriatrics and dependency. They include:

- the Regional Disability Centre (Sarthe) ${ }^{68}$ dedicated to the care of patients with severe physical disabilities,

- the Billiers Aftercare and Rehabilitation Centre (Morbihan) ${ }^{69}$ : a health establishment participating in the Public Hospital Service that provides psychiatric aftercare for adults with stabilized mental pathologies,

- the "Les Quatre Vents" vacation centre (Vendée) ${ }^{70}$, which includes an ESAT that enables men and women with mild to moderate disabilities to work in this vacation centre,

- Psy'Activ (Loire Atlantique) ${ }^{71}$, association which works for people suffering from psychic disorders by helping them to find a better autonomy thanks to rehabilitation and stabilization tools,

- the Maurs Rehabilitation Centre (Cantal) is a psychiatric aftercare facility that supports young adults whose disorders lead to a loss of social, professional and relational skills ${ }^{72}$,

- the Medico-social Centre of Coulomme (Pyrénées-Atlantiques) ${ }^{73}$ which includes an Alzheimer unit and rooms for follow-up care and rehabilitation.

The Solidel national association ${ }^{74}$. In addition, the Solidel national association, created in 1992 by the MSA, promotes the inclusion of people with disabilities in rural areas.

67. Mutualité sociale agricole (MSA), La politique d'action sanitaire et sociale, https//www.msa.fr/lsy/ politique-action-sanitaire-et-sociale, access 16.06.2020.

68. Pôle Régional du Handicap (PRH), https://asso-prh.fr, access 16.06.2020.

69. Ibidem.

70. Les Quatre Vents, www.quatrevents.com, access 16.06.2020.

71. Association Psy'Activ, www.psyactiv.fr, access 16.06.2020.

72. Centre de Réadaptation, https://www.soinsrehabpsy.fr, access 16.06.2020.

73. Essentiel Autonomie, https://www.essentiel-autonomie.com, access 16.06.2020.

74. Solidel, www.solidel.fr, access 16.06.2020. 
It federates 26 MSA funds, 42 associations managing ESATs (Establishment and service of help by work) and EAs (Adapted companies), support and accommodation structures, and social life support services. These establishments accommodate 4,100 disabled workers.

The MSA's recognized expertise in the field of disability. To validate its status as a social welfare organization with expertise in disability, the MSA applied for membership in the National Advisory Council for the Disabled (fr. Conseil National consultative des Personnes Handicapées - $\mathrm{CNCPH}$ ) and was selected as an expert member in early 2020.

Its expertise is manifested through innovative actions in favour of people with disabilities with the aim of facilitating their lives (digital accessibility) and accompanying them in terms of preventive health in the field of nutrition and oral health.

The MSA has placed at the heart of its objectives the implementation of its social and societal responsibility dynamic and the MSA 2025 orientations focus in particular on the issues of Health Prevention, Dependency and Disability in a territorial approach.

Its mission as an agricultural social protection organization and as a player in the health and social development of rural areas has led it to give a voice to people with disabilities and their families living in rural areas, based on the expression of their needs, in order to make them active participants in decision-making.

By acting with the different types of actors, such as local authorities, the education sector, ARS, associations, companies, etc., the MSA's desire is to contribute fundamentally to the evolution of society towards a truly inclusive approach at all stages of the lives of people with disabilities.

Thus, the MSA is present on many fronts, but its desire to meet the needs expressed by rural populations does not stop at the borders of France. For many years, it has also been active on an international scale.

\section{MSA's action in Europe and internationally}

At the international level, the MSA acts in favour of the development of social protection. This is reflected in its active participation in organizations working for the dynamics of European social protection and its involvement in international cooperation projects. 


\section{In Europe}

The MSA is present in Brussels via the European Representation of French Social Protection Institutions (REIF), which groups together all the French compulsory social protection schemes. Due to its representation in the various institutions and bodies of the European Union, REIF defends the values and interests of French social security ${ }^{75}$.

It is a member of the European Social Security Platform (ESIP), an organization that brings together the national social security funds of the Member States to speak for systems based on solidarity. This platform enables the collegial follow-up of social issues on the EU agenda and promotes knowledge sharing between its members ${ }^{76}$.

The MSA is a founding member of the ENASP network (European network of agricultural social protection systems) which brings together the six autonomous agricultural social protection schemes (Germany, Austria, Finland, France, Greece, Poland). ENASP is above all a forum for technical cooperation, information sharing and best practices. In particular, it takes the form of an annual forum where all current European issues relating to the missions and specificities of its members are discussed ${ }^{77}$.

\section{On an international scale}

The MSA is a member of the ISSA (International Social Security Association), and as such participates in the work of the International Committee for the Prevention of Occupational Risks in Agriculture and in the work of the Mutuality Technical Commission $^{78}$.

It is also present at the AIM (International Association of Mutual Benefit Societies - fr. Association Internationale de la Mutualité), where it is involved in the work of the European zone.

It has also been involved in two long-standing partnerships:

75. La REIF (Représentations des Institutions Françaises de sécurité sociale auprès de l'Union européenne), http://www.reif-org.eu, access 16.06.2020.

76. European Alliance In Social Insurance (ESIP), https://esip.eu, access 16.06.2020.

77. European Network of Agricultural Protection Systems (ENASP), http://www.enasp.eu, access 16.06.2020.

78. International Social Security Association (ISSA), https://ww1.issa.int/fr, access 16.06.2020. 
In Tunisia, with the National Social Security Fund (French: CNSS): the partnership, initially established in 2009 by a European institutional twinning coordinated by the MSA, continues in the form of technical cooperation in all areas of social protection by support missions of French experts in Tunisia and study visits of Tunisian experts in France ${ }^{79}$.

In West Africa, with the Inter-African Conference on Social Security (French: CIPRES): since 2011, a partnership in the form of annual training seminars designed for directors and experts of Cipres member organizations on issues identified by mutual agreement and led by MSA experts. Audit, information system, health insurance, risk mapping, HR functions, communication, information systems, management by objectives are some examples of the topics that have been developed ${ }^{80}$.

In addition, the MSA regularly receives foreign delegations both at the Central Fund and in the network, in response to requests from various foreign organizations or institutions such as social security funds, social welfare institutions, ministries, professional agricultural organizations, as well as universities or research centres.

\section{Bibliography}

Act no. 61-89 of 25 January 1961, Official Journal of the French Republic (JO) no. 0023, 27 January 1961. Act no. 72-965 of 25 October 1972, Official Journal of the French Republic (JO) no. 0251, 26 October 1972. Act no. 74-1094 of 24 December 1974, Official Journal of the French Republic (JO) no. 0301, 26 December 1974 .

Act no. 90-1168 of 29 December 1990, Official Journal of the French Republic (JO) no. 0303, 30 December 1990 .

Act no. 2002-308 of 4 March 2002, Official Journal of the French Republic (JO) no. 0054, 5 March 2002. Act of 9 October 2010 on pension reform.

Association Psy'Activ, www.psyactiv.fr, access 16.06.2020.

AVMA (Association de Vacances de la Mutualité Agricole), https://www.avma-vacances.fr, access 16.06.2020.

Caisse Nationale de Sécurité Sociale, www.cnss.nat.tn, access 16.06.2020.

Centre de Réadaptation, https://www.soinsrehabpsy.fr, access 16.06.2020.

Conférence interafricaine de la Prévoyance Sociale (C.I.PRE.S), www.lacipres.org, access 16.06.2020.

Decree-Law of 30 October 1935.

Decree-Law of 29 July 1939.

Essentiel Autonomie, https://www.essentiel-autonomie.com, access 16.06.2020.

79. Caisse Nationale de Sécurité Sociale, www.cnss.nat.tn, access 16.06.2020.

80. Conférence interafricaine de la Prévoyance Sociale (C.I.PRE.S), www.lacipres.org, access 16.06.2020. 
European Alliance in Social Insurance (ESIP), https://esip.eu, access 16.06.2020.

European Network of Agricultural Protection Systems (ENASP), http://www.enasp.eu, access 16.06.2020.

Fédération Nationale des Marpa, https://www.marpa.fr, access 16.06.2020.

Gouvernement, Conseil National Consultatif des Personnes Handicapées (CNCPH), https//www.gouvernement.fr/conseil-national-consultatif-des-personnes-handicapees-cncph, access 16.06.2020.

International Social Security Association (ISSA), https://ww1.issa.int/fr, access 16.06.2020.

La REIF (Représentations des Institutions Françaises de sécurité sociale auprès de l'Union européenne), http://www.reif-org.eu, access 16.06.2020.

La Sécurité sociale, www.securite-sociale.fr, access 16.06.2020.

Les Quatre Vents, www.quatrevents.com, access 16.06.2020.

Mutualité sociale agricole (MSA), Accident, maladie, invalidité, https://www.msa.fr/lfy/sante/accident-maladie-invalidite, access 16.06.2020.

Mutualité sociale agricole (MSA), Accompagner les personnes en difficulté, https//www.msa.fr/lsy/solidarite/accompagner-personnes-difficulte, access 16.06.2020.

Mutualité sociale agricole (MSA), Famille, lodgement, https://www.msa.fr/lfy/famille-logement, access 16.06.2020.

Mutualité sociale agricole (MSA), L'allocation aux adultes handicapés (AAH), https://www.msa.fr/lfy/ handicap/allocation-adultes-handicapes, access 16.06.2020.

Mutualité sociale agricole (MSA), L'allocation veuvage, https://www.msa.fr/lfy/web/msa/retraite/allocation-veuvage, access 16.06.2020.

Mutualité sociale agricole (MSA), La politique d'action sanitaire et sociale, https//www.msa.fr/lsy/politique-action-sanitaire-et-sociale, access 16.06.2020.

Mutualité sociale agricole (MSA), La retraite des non-salariés agricoles, https://www.msa.fr/lfy/web/ $\mathrm{msa} /$ retraite/non-salaries-agricoles, access 16.06.2020.

Mutualité sociale agricole (MSA), La retraite des salariés agricoles, https://www.msa.fr/lfy/web/msa/retraite/salaries-agricoles, access 16.06.2020.

Mutualité sociale agricole (MSA), Le concours "Appel à projets jeunes", https://www.msa.fr/lfy/evenements/apj, access 16.06.2020.

Mutualité sociale agricole (MSA), Le congé de paternité et d'accueil de l'enfant, https://www.msa.fr/lfy/ $\mathrm{web} / \mathrm{msa} /$ sante/conge-paternite, access 16.06.2020.

Mutualité sociale agricole (MSA), Le congé maternité, https://www.msa.fr/lfy/web/msa/sante/conge-maternite, access 16.06.2020.

Mutualité sociale agricole (MSA), Le mutualisme, une force, https://www.msa.fr/lfy/identite/le-mutualisme, access 16.06.2020.

Mutualité sociale agricole (MSA), Le RSA, mode d'emploi, https://www.msa.fr/lfy/rsa/mode/emploi, access 16.06.2020

Mutualité sociale agricole (MSA), Les chiffres utiles de la MSA - Edition nationale 2019, statistiques.msa. fr, access 16.06.2020. 


\section{MSA, The French Agricultural Social Protection scheme}

Mutualité sociale agricole (MSA), Les élus porteurs de l'innovation sociale. Rapport mutualiste 2018, https://www.msa.fr/lfy/documents/11566/82466756/Rapport+mutualiste+MSA+2018.pdf, access 16.06.2020

Mutualité sociale agricole (MSA), L'indemnité journalière Amexa pour les exploitants et leur famille, https://www.msa.fr/lfy/web/msa/sante/ij-amexa, access 16.06.2020; Mutualité sociale agricole (MSA), L'arrêt de travail pour maladie des salaries, https://www.msa.fr/lfy/web/msa/sante/arret-travail-maladie, access 16.06.2020.

Mutualité sociale agricole (MSA), L'invalidité et l'inaptitude médicale au travail, https://www.msa.fr/lfy/ $\mathrm{web} / \mathrm{msa} /$ sante/invalidite-inaptitude, access 16.06.2020.

Mutualité sociale agricole (MSA), La MSA, https://ssa.msa.fr/a-propos, access 16.06.2020.

Mutualité sociale agricole (MSA), Maintien emploi travailleurs agricoles, https://www.msa.fr/lfy/solidarite/maintien-emploi-travailleurs-agricoles, access 16.06.2020.

Mutualité sociale agricole (MSA), Mutualism in MSA, https://www.msa.fr/lfy/identite/le-mutualisme, access 16.06.2020.

Mutualité sociale agricole (MSA), Pension de reversion, https://www.msa.fr/lfy/web/msa/retraite/reversion), access 16.06.2020.

Mutualité sociale agricole (MSA), Présentation de la MSA, https://www.msa.fr/lfy/identite/nos-valeurs, access 16.06.2020.

Mutualité sociale agricole (MSA), Prévention santé MSA nos actions sur les territoires en 2018, https:// www.msa.fr/lfy/actions-partenaires/prevention-sante-atout-majeur-msa, access 16.06.2020.

Mutualité sociale agricole (MSA), Qu'est-ce qu’un élu MSA?, https://www.msa.fr/lfy/elections-msa/ delegue-cantonal, access 16.06.2020.

Mutualité sociale agricole (MSA), Risques biologiques et zoonoses, https://ssa.msa.fr/risque/risques-biologiques-et-zoonoses/, access 16.06.2020.

Mutualité sociale agricole (MSA), Risques chimiques, https://ssa.msa.fr/risque/risques-chimiques/, access 16.06.2020.

Mutualité sociale agricole (MSA), Risques de chutes, https://ssa.msa.fr/risque/risques-de-chutes/, access 16.06.2020.

Mutualité sociale agricole (MSA), Risques psychosociaux, https://ssa.msa.fr/risque/risques-psychosociaux/, access 16.06.2020.

Mutualité sociale agricole (MSA), The populations of the agricultural scheme in 2016 - Statistical yearbook, statistiques.msa.fr, access 16.06.2020.

Mutualité sociale agricole (MSA), Troubles musculosquelettiques, https:/ssa.msa.fr/risque/troubles-musculosquelettiques/, access 16.06.2020.

Mutualité sociale agricole (MSA), Votre couverture santé MSA, https://www.msa.fr/lfy/sante/couverture-msa, access 16.06.2020.

Mutualité sociale agricole (MSA), Vous avez perdu un proche, https://www.msa.fr/lfy/pratique/vousavez-perdu-un-proche, access 16.06.2020. 
Official Journal of the French Republic (JO) no. 0104, 1 May 1930.

Official Journal of the French Republic (JO) no. 0184, 7 August 1936.

Official Journal of the French Republic (JO) no. 316, 7 December 1940.

Official Journal of the French Republic (JO) no. 0279, 1 December 2001.

Order no. 96-344 of 24 April 1996, Official Journal of the French Republic (JO) no. 0098, 25 April 1996.

Pôle Régional du Handicap (PRH), https://asso-prh.fr, access 16.06.2020.

Présence Verte, https://www.presenceverte.fr, access 16.06.2020.

Rural and Maritime Fishing Code.

Social Security Code, Article L. 861-1.

Social Security Code, Articles L.134-7 to L.134-11.

Social Security Financing Act for 2014.

Social Security Financing Act for 2016.

Social Security Financing Act for 2019.

Solidel, www.solidel.fr, access 16.06.2020.

The 1963 Finance Act no. 63-156 of 23 February 1963, Official Journal of the French Republic (JO) no. 0047, 24 February 1963.

This article is licensed under a Creative Commons Attribution 4.0 International license (CC BY 4.0) 